\title{
Article \\ Obstacle Comparisons to Achieving Distance Learning and Applying Electronic Exams during COVID-19 Pandemic
}

\author{
Raed Bashitialshaaer ${ }^{1, *(\mathbb{D})}$, Mohammed Alhendawi ${ }^{2}$ and Zohra Lassoued $^{3}$ \\ 1 Center for Middle Eastern Studies, Lund University, Box 201, 22100 Lund, Sweden \\ 2 Education and Psychology, Al-Azhar University, Gaza Box 1277, Palestine; abu-hithm@hotmail.com \\ 3 College of Social and Human Sciences, El Oued University, El Oued 39000, Algeria; \\ lassouedzohra2016@gmail.com \\ * Correspondence: raed.bashitialshaaer@cme.lu.se or ralshaaer@yahoo.com; Tel.: +46-736-893-445
}

Citation: Bashitialshaaer, R.;

Alhendawi, M.; Lassoued, Z. Obstacle Comparisons to Achieving Distance Learning and Applying Electronic Exams during COVID-19 Pandemic. Symmetry 2021, 13, 99. https:// doi.org/10.3390/sym13010099

Received: 19 November 2020

Accepted: 5 January 2021

Published: 8 January 2021

Publisher's Note: MDPI stays neutral with regard to jurisdictional clai$\mathrm{ms}$ in published maps and institutional affiliations.

Copyright: (C) 2021 by the authors. Licensee MDPI, Basel, Switzerland. This article is an open access article distributed under the terms and conditions of the Creative Commons Attribution (CC BY) license (https:// creativecommons.org/licenses/by/ $4.0 /)$.

\begin{abstract}
This study aims to identify obstacles and barriers to achieving quality distance learning and the use of electronic exams, comparing them to pursue success in the distance education system during the coronavirus pandemic (COVID-19). It also aimed to determine the similarity and differences between the two main components of distance education. This is based on a sample of evaluations from professors and students at universities in the Arab world, i.e., Algerian, Egyptian, Iraqi, and Palestinian universities. We used a descriptive approach using questionnaires (open question) with conveniently selected samples from two different groups: (1) 400 professors and student's feedback from 600 distributed (i.e., Algerian, Egyptian, Palestinian, and Iraqi) and (2) 152 professors and student's feedback from 300 distributed (i.e., Palestinian universities in the governorates of Gaza). The results indicated that professors and students faced 27 barriers in both distance learning and electronic exams, which are divided into four groups (categories) according to the sample. Recommendations to understand and overcome these obstacles will also be presented to improve distance learning and e-exams in the future. It is important to coordinate efforts in the development of distance education, especially concerning universities using distance learning and e-exams.
\end{abstract}

Keywords: obstacles comparison; distance learning; electronic testing (e-exams); professors and students; COVID-19 pandemic

\section{Introduction}

This study aims to investigate and identify the type of relationship between the obstacles and barriers to achieving quality distance learning and the use of electronic exams and compare them to pursue success in the distance education system during the COVID-19 pandemic. We are trying to benefit from this relationship (whether the obstacles are synonymous or opposite to each other) between the two components or faces of the distance education system by putting them side by side for comparison purposes. For example, after this comparison between obstacles from the two groups, we want to see if they can represent each other, in which this relationship can be used for a similar study in the future and benefit from it as much as possible elsewhere.

Educators were forced to switch to online teaching through electronic learning and testing systems after the World Health Organization declared that COVID-19 was a pandemic $[1,2]$. Today, higher education institutions face several challenges imposed on them by successive scientific and technological developments.

Despite the limited skills and resources at their disposal, these institutions are confronted with a growing demand for higher education, efficiency, and quality that is not limited to traditional classroom teaching. Social and technological developments have been accompanied by changes in education, including higher education. Research in this field has documented the adaptation and impact of information and communication 
technologies (ICT) in higher education over the last three decades and speculated on future trends [3]. Of particular importance for higher education in the Arab world is the question of how ICT and other types of technology can be linked to the challenges of development, as demographic pressures remain high in most Arab countries, e.g., Algeria, Egypt, Palestine and Iraq.

Perhaps the challenge that faces many educators and occupies the thinking of many faculty, students, and parents is how to evaluate performance and how reliable this evaluation really is. As the educational evaluation is considered one of the important and necessary matters in education, it can guide us to the strengths and weaknesses and to what extent the educational process has been reached. The educational evaluation derives its importance through the use of many methods and tools, and thus this leads us to know the individual differences and the level of students' abilities [4].

In the e-tests (E-assessment), the evaluation is one of the modern approaches for the development of the educational process, though it is possible to identify the impact of what has been planned through the teaching and learning processes, as well as the strengths and weaknesses in them, leading to the development of solutions that contribute to emphasizing support for strengths and avoiding weaknesses [5]. The concept of educational evaluation in its simple sense is to collect and analyze data aimed at determining the degree of achievement of goals to make decisions and address deficiencies. This can be done in several ways, including remote evaluation (E-assessment) [6,7]. Internet connections must be good, with immediate student feedback, enabling an alternative to face-to-face teaching [8]. Adapting to an online teaching system during the crisis is the biggest challenge for teaching and learning solutions that institutions can develop to cope with the pandemic [9].

As an example, the Palestinian Al-Quds Open University was the first to establish a distance learning university in the Arab world. Other Arab initiatives were subsequently announced, including the Open University in Tripoli, Libya, which has numerous branches in Libyan cities, the university Continuing Training in Algeria and the virtual university in Syria. In addition to Egypt's experience in using distance education to train teachers, there are preliminary projects for distance education in Yemen, Morocco, Lebanon and other Arab countries [10].

Today, with the emergence of the COVID-19 pandemic, governments are forced to close educational institutions, denying $89 \%$ of learners (i.e., more than 1.5 billion people) in 188 countries access to education [11]. Arab universities are trying to revitalize the distance education system to continue to provide educational activities for students. This sudden shift to distance learning in an emergency situation has caused shock and tension among students and faculty members, both personally and professionally, as this process requires additional efforts in addition to some unusual obstacles for schools and universities such as lack of time, poor infrastructures and inappropriate digital content [12]. Reliability and sufficient availability of technological infrastructures, such as learning tools and digital learning resources in the form of online courses, e-books and e-notes, are of utmost importance in such a critical situation [13].

Girik studied the perception of online learning during the COVID-19 pandemic where learners wished to have explanations preceding the material and tasks and recommended the use of special media such as voice notes. His study not only reported that online learning is appropriate during the COVID-19 pandemic but also addressed the issues of availability of internet access (free), provide some assistance in solving financial issues and other online learning applications [14]. Al-Ghomlas [6] indicated that the remote evaluation process is an important part of the online education process, including technological development, especially the operational capacity of devices, which made many teachers encourage the use of electronic tests when evaluating students, and this is confirmed in $[14,15]$.

Electronic tests are considered important for teachers themselves in evaluating their students in every academic course, as many studies have confirmed that electronic tests allow teachers over time to measure correctly the educational content so that these para- 
graphs represent the area of behavior to be measured (the scientific material) or what is known as a question bank [16]. In addition, these tests can contribute to increasing the motivation of the learner to learn through tests of appropriate items that measure the educational tasks given to students with different achievement abilities [17]. In addition to the above, low-achieving students have a superior ability to prefer the structural test over electronic tests. The presence of advanced devices can make the electronic link process easy and fast for all students with adequate protection programs to avoid leakage of questions to them [4].

\subsection{Objectives}

The present study aims to examine and compare the obstacles to distance learning and the use of electronic exams from the specific perspective of professors and students at some Arab universities, in order to help those involved in the educational process to avoid these obstacles and the success of electronic exams that can lead to the success of the whole distance education system. A sub-objective is also to ask questions about the obstacles to achieving both high-quality distance education and high-quality electronic examinations from the perspective of faculty members of some Arab universities and their students. Therefore, the main objectives of this study:

1. Specifying the obstacles faced by the university professors and students in achieving quality in the use of e-learning during the COVID-19 pandemic.

2. Specifying the obstacles faced by professors and students at the Palestinian universities in the governorates of Gaza in achieving quality in the use of e-testing during the COVID-19 pandemic.

3. Comparing the obstacles between 1 and 2 for achieving the quality of distance education.

4. Classifying and ordering these obstacles to understand how they can be reduced in the future.

5. Finding the diverging (non-shared) obstacles and describing them.

6. Make final suggestions to overcome these obstacles.

\subsection{Major Questions of This Study}

This study coincided with the global COVID-19 pandemic, which has become a barrier to education systems around the world, particularly for universities in the Arab world. During this pandemic, Arab universities have introduced a system of distance learning and electronic exams as an alternative to traditional teaching in order to complete the educational activities remaining until the end of the academic year. From this point of view, the motivation was to raise questions about the obstacles to the use of e-exams following distance learning and to help find possible solutions to reduce these obstacles. The main questions in this study are therefore as follows:

1. Is there a difference between the obstacles to achieving the quality of distance learning and the obstacles to applying electronic tests from the viewpoint of university professors and students during the COVID-19 pandemic?

2. What is the order of these obstacles, what are the benefits of ordering them?

3. How are these obstacles arranged from the viewpoint of university professors and students, and overall?

\subsection{Delimitation of the Study}

In this study, a large sample was collected after the distribution of a general open question among several professors and students from different universities without any restriction as to which subject they are studying, as described below:

- Regions: The study included some of the Arab countries (i.e., Algerian, Egyptian, Palestinian, and Iraqi universities).

- Period: The study was conducted in April and May 2020 and in September and October 2020. 
- Sample: The study included university professors and students from different subject area.

We have chosen the online survey as it allows us to reach a maximum number of samples in a limited time using an online questionnaire where a general question was built in (e.g., Word document and Google form) and then sent by email to collect answers from professors and students from different departments and faculties.

The data were collected in the periods April-May 2020 and September-October 2020, resulting in a return of 400 (100 professors and 300 students) from about 600 used forms and a return of 152 (97 professors and 55 students) from about 300 used forms, respectively. The study data were collected for professors in Iraq (22), Algeria (28), Egypt (26), and Palestine (121) and students in Iraq (55), Algeria (100), Egypt (85), and Palestine (115).

From the beginning, we worked on the data collection as a total for professors and students because of the difficulties that were faced in the process, e.g., collection, counting, filling the Word document and sending it back and weak internet; therefore, the presented numbers are (the error is in the range of $10 \%$ ) the approximate distribution but very accurate in totals.

\section{Theoretical Framework and Exploratory Procedures}

\subsection{Distance Learning}

\subsubsection{Concept of the Distance Learning}

Online education (distance education) has increased at many universities in China, including overnight shifts of normal classrooms into e-classrooms during the COVID-19 pandemic trying to adapt to the new situation [18]. The concept of distance education is considered as an approach, to the education system, that is not fully under educational philosophy. It is carried out without direct contact with the professor, students can learn according to what their time allows and in the place (i.e., at home, in the workplace, or in an educational center). Hence, the use of technology in distance education is an important element [9].

Long ago, Holmberg [19] defined distance learning as "is a method that includes all of the study levels of education that do not have direct contact and continuous supervision by teachers attend with their students as in traditional classrooms, in which this process is subject to planning, organization, and directed by an educational institution and teachers" [20]. Another definition was made by the American Association for Distance Learning (USDLA) as "the process of acquiring knowledge through a variety of media used to transfer education and information, including all types of technology and various forms of education level for distance learning" [21].

Accordingly, distance learning is an educational system that requires communication between the teacher and the student through multiple media to exchange information, such as publications, and educational media via modern audio-visual technologies. Online learning is also defined as learning experiences in synchronous or asynchronous environments through different technologies (e.g., mobile phones, tablets, laptops), so students can be anywhere while they learn and interact with teachers and share their ideas with colleagues simultaneously [22].

Obstacles to achieving quality in distance learning by professors and students of some Arab universities are defined as some barriers that prevent the achievement of quality in the educational learning process according to the distance learning system during the COVID-19 pandemic.

\subsubsection{The Distance Learning System}

In the mid-nineteenth century, distance learning was established and started as a form of continuous higher education, and in 1858, the University of London granted degrees to students without attending classes, while a royal agreement was issued in 1896 for the examination of students studying by correspondence at the University of London, followed by other universities. For example, the University of St. Andrews in Scotland had more 
than a hundred centers around the world between 1877 and 1931, such as in China and Kenya. In 1946, the University of South Africa was the first university to introduce an entire distance education system, and the French National Distance Learning Center (CNED) [23].

Technological developments led to a variety and forms of distance education in the modern-day, beginning with the correspondence education system, education through a media, the use of the educational phone and interactive video, and the educational computer which used the internet to achieve progress in the field of education from a distance.

The present digital technologies are considered in the earlier forms of distance learning that provide perspectives both on the historical rationales of such education, and suggestions on alternative forms of the education system.

Due to the high cost of the traditional education system for such learners, and for adult learning with families, moving to another town was not always an option; historically, distance learning was established to address the needs of adult learners who could not take years away from their professional lives for full-time and part-time studies at a university level [24]. More reasons for distance education, among this, the need to serve distant rural locations and poor areas, and in other cases this format was motivated by colonial projects, aiming to gain influence over populations across the world.

\subsubsection{Distance Learning Characteristics}

Distance learning can be characterized as a new method of education and adopts some methods that are considered to be different from those used in the traditional education system [25].

There are several methods used to transfer information to learners that are different from the ones used in traditional education, e.g., flexibility in acceptance and learning, as the learner can receive their education at anytime and anywhere; this type of education is less expensive than other education systems [25,26].

The need for access to a safe and high-quality/speed internet connection and specifications are all important to learners, dependent on where they are living, which leads to quick access to prepared data and information. Hence, this must be a secured process in the exchange between the network user and internet service provider, specifically during electronic exams [27].

However, we have to consider all important obstacles that hinder distance learning, e.g., shortages of teachers and the need for training and experience in the use of the internet by teachers and students and covering the lack of technological infrastructure at some universities [27].

Lack of direct interaction and communication between the teachers and the learners is considered as one of the major disadvantages of information communication technologies mediated in distance learning; this type of learning is currently deficient in providing human and social expression and accepts low grades as a flexibility basis, which is a weak point when compared to the traditional system $[25,26]$.

\subsection{Electronic Tests}

\subsubsection{Electronic Tests Concept}

Electronic tests are objective and computerized tests consisting of different models given to students in which randomization is used when selecting the questions for each model [28].

Refers to tests that are performed through the computer, where the test items are displayed, and the student answers them directly [29].

Electronic tests are a group of stimuli that are organized and arranged in a specific way and are used in schools, universities and admission centers in order to identify individual differences between people [30].

Obstacles facing electronic testing refer to factors that prevent the application of electronic tests according to the distance education system, which is specified by profes- 
sors (everyone who works as a faculty member) and students (all students in the same universities) of some Palestinian universities.

\subsubsection{Characteristics of Electronic Tests}

A number of researchers have identified the characteristics of electronic tests, among them [31], who indicated that there are five characteristics of electronic tests: interactivity, flexibility, time-saving ability, immediate feedback, shortening of resources and recordkeeping. Wiechmann and Ryan [32] indicate that electronic tests are often used to increase standardized tests and provide time to correct and reduce financial costs.

Bennett [33] added other characteristics such as ease of reviewing the test items, saving the cost of printing, providing dynamic stimuli in sound, image and animation without the need for other devices, giving students scores instantly and without bias, and reducing the need for correctors to read and review and distribute test results without the cost of printing and sending reports.

De Beer and Visser [34] added that the safety, time savings, the accuracy of results, and speed of correction are among the essential advantages of electronic tests, and this is confirmed by Schmit and Ryan [35], noting that among the advantages of electronic tests are the ease of procedure, automatic correction, and reduction in correction errors in paper tests.

\subsubsection{Disadvantages of Electronic Tests}

Electronic tests have a number of disadvantages that researchers have observed. Bennett [33] states that one of the most important disadvantages of electronic tests is that preparing them consumes a long time as they require skills and training for the preparation and implementation processes. He adds that measuring higher skills is one of the difficulties faced in computerized tests because it depends—in general—on the quality of the objective tests, and the possibility of hardware malfunctions is a possibility during the test.

In addition, electronic tests require good skills and experience in information technology by the student and the professor, and this requires adequate training.

Additionally, other researchers point to various fundamental defects. Harrison and Bergen [36] believe that one of the most important defects of electronic tests is cheating. The person who presented the test on the screen may be someone other than the student. One study confirms that one of the defects of electronic tests is the inability for reviewing questions, the inability to change answers, the inability to ignore some questions, as well as the existence of problems related to the examiners' motivation, and this may affect the examinees and lose credibility in the equality of results between paper and electronic tests [37].

\subsection{Selected Previous Studies}

Many important parameters need to be considered when adapting to e-learning, e.g., instruction, content, motivation, relationships and mental health, which the trainer and the recipient need to keep in mind when participating in the system [38]. George [39], in his recent research, was concerned about student feedback on distance learning and highlighted the key benefits that students gained from learning during the COVID-19 pandemic. The teaching system in this study was feasible and could be adopted for teaching, even if it was not a pandemic.

The recent study by Lassoued et al. [24] aimed to identify obstacles to achieving quality distance learning in light of the coronavirus pandemic, using a sample of professors and students from some Arab universities. The results showed that the professors and students faced four groups of obstacles, i.e., personal obstacles, pedagogical obstacles, technical obstacles, material and organizational obstacles. James [40] investigated the attitude of students towards the use of electronic tests at the University of New England in Australia. The study concluded that the challenges were related to internet speed, the 
test system itself and the technical problems associated with it. In addition, there was a lack of test confidentiality, as there is no security system that can be trusted for electronic testing. Liu et al. [15] investigated the acceptance and perception of students regarding the improvement of electronic testing for the community college in Taiwan. The researchers used a questionnaire consisting of 20 questions. The results for electronic testing showed that students responded positively and that the test subjects themselves have confidence in the testing procedures.

The study by Stowell and Bennett [41] was based on the hypothesis of presenting the tests electronically to reduce the testers' fear of testing. The results showed that students who normally suffer from test anxiety while taking traditional tests had significantly reduced their test anxiety rate. In contrast, the study showed that students who do not normally suffer from exam anxiety while taking paper tests increased their fear rate when taking electronic tests. Thomas et al. [42] examined the barriers to the use of electronic testing in higher education in particular, the problem of testing in general, and electronic testing in particular. In addition to the obstacles related to the continuity of the internet connection throughout the test period, the study examined the experience of conducting tests over the internet, either in a synchronized manner, in which the student is in contact throughout the test period, or an asynchronous manner, in which the student downloads the test and then re-sends it within a certain period. The results of the study showed the effectiveness of this type of electronic testing in reducing the students' anxiety.

\section{Data Collection and Procedures}

\subsection{Study Approach and Method}

This is a descriptive comparative study that attempts to describe and visualize obstacles to the electronic education system at some universities in Arab countries. This study used two groups, the first group (i.e., Algeria, Egypt, Palestine, and Iraq) was made to explore obstacles facing distance learning and the second group (Palestinian universities located in the governorates of Gaza) was made to explore obstacles facing electronic exams, as shown in Table 1.

Table 1. Distribution of the members of the study samples.

\begin{tabular}{ccccc}
\hline \multirow{2}{*}{ Targeted People } & \multicolumn{2}{c}{ Distance Learning } & \multicolumn{2}{c}{ Electronic Exams } \\
\cline { 2 - 5 } & $\begin{array}{c}\text { Total } \\
\text { Number }\end{array}$ & $\begin{array}{c}\text { Percentage } \\
\mathbf{( \% )}\end{array}$ & $\begin{array}{c}\text { Total } \\
\text { Number }\end{array}$ & $\begin{array}{c}\text { Percentage } \\
\mathbf{( \% )}\end{array}$ \\
\hline University professors & 100 & 25 & 97 & 63.8 \\
University students & 300 & 75 & 55 & 36.2 \\
Total & 400 & 100 & 152 & 100 \\
\hline
\end{tabular}

In this study, we have chosen the online survey as it allows us to reach a maximum number of samples in a limited time since the research purpose was to collect updated information on an ongoing pandemic situation. We could not use the previously applied and approved methodologies; because this is an exploratory and descriptive study, an online questionnaire (general question made through Google Forms) was used to collect answers from all university members (professors and students) from different departments and faculties.

In the first group, about 600 questionnaires were used with a return consisting of 400 professors and students. For the second group, more than 300 questionnaires were sent and 152 were returned by professors and students. Professors and students have received the questionnaires mostly by email as an online survey method and some of them were sent personally. The difference between the professors' and students' return was because of a weakness in the response to the measurement tool by faculty members and the availability of internet access for the faculty members from their working places. 


\subsection{Study Tool}

To assess obstacles to applying electronic tests in the distance education system during the coronavirus (COVID-19) pandemic, the authors distributed an electronic form that included an open question to the professors and students of the Palestinian universities. Since the study is descriptive and aims to identify obstacles, the responses were subjected to statistical treatment (analysis). The study did not address these correlations because it does not search for the causes of the phenomenon; rather it is limited to identifying and comparing the obstacles to achieving the quality of distance learning and the obstacles to applying the electronic tests in specific areas (subjective, pedagogical, etc.). Then it highlighted the differences in the professors' and students' opinions about these obstacles in order.

\subsection{Obstacles Category and Comparison}

In total, 14 obstacles were specified from distance learning questionnaires and 13 obstacles were specified from electronic exam questionnaires. Thus, these were put into four different categories as shown in Table 2. For instance, the distance learning obstacles were categorized as follows: five obstacles were defined as personal obstacles (self-imposed obstacles), three obstacles were defined as pedagogical obstacles, two obstacles were defined as technical obstacles and four obstacles were defined as financial and organizational obstacles. The obstacles for electronic exams were categorized as follows: four obstacles were defined as personal obstacles (self-imposed obstacles), three obstacles were defined as pedagogical obstacles, three obstacles were defined as technical obstacles, and three obstacles were defined as financial and organizational obstacles.

In Table 2, for distance learning, the overall percentage column is the summation of professors' and students' repetition for each obstacle divided by their total number $(n=400)$ and then followed by an obstacle order number, which was performed for electronic exams obstacles for $(n=152)$.

Some professors were not convinced of the usefulness of distance learning $(14.8 \%)$, the difficulty of their understanding of some subjects in the absence of class interaction $(58.8 \%)$, weak internet flow (speed) (59), and the lack of training in the use of technology (35\%). In general, we observed that the total responses from both professors and students were below $50 \%$ (11 out of 14 obstacles) while just three obstacles were above $50 \%$.

Similarly, for the electronic exam selection, university professors and students attributed the obstacles to achieving quality when applying electronic tests as electronic tests will not show the true level of students and will not distinguish students from others $(45.4 \%)$, and power cuts (lack of electricity, 66.4\%). It was claimed that some teachers do not have sufficient experience to prepare and apply the test (23\%), difficulty and poor study in light of difficult conditions (57.2\%), and unavailability of the internet and poor internet quality (57.9\%). In general, we noticed that the total responses from both professors and students were nine obstacles below $50 \%$, while only four obstacles were above $50 \%$. 
Table 2. Obstacle comparisons between achieving the quality of distance learning (excerpted from [24]) and applying electronic exams under the coronavirus pandemic.

\begin{tabular}{|c|c|c|c|c|}
\hline $\begin{array}{l}\text { Obstacles } \\
\text { Category }\end{array}$ & $\begin{array}{l}\text { Distance Learning } \\
\text { Obstacles }\end{array}$ & $\begin{array}{l}\text { Overall } \\
\text { Percentage } \\
(\%) \text { Order }\end{array}$ & $\begin{array}{l}\text { Electronic Exams } \\
\text { Obstacles }\end{array}$ & $\begin{array}{l}\text { Overall } \\
\text { Percentage } \\
\text { (\%) Order }\end{array}$ \\
\hline \multirow{5}{*}{$\begin{array}{c}\text { Personal obstacles } \\
\text { (self-imposed obstacles) }\end{array}$} & $\begin{array}{l}\text { 1-The weak motivation of } \\
\text { students to distance learning. }\end{array}$ & (44.3) 4 & $\begin{array}{l}\text { 1-Difficulty and poor study } \\
\text { during critical conditions. }\end{array}$ & $(57.2) 4$ \\
\hline & $\begin{array}{l}\text { 2-Some professors are not } \\
\text { convinced of the usefulness of } \\
\text { distance learning. }\end{array}$ & (14.8) 14 & $\begin{array}{l}2 \text {-Parents are not convinced } \\
\text { of Electronic tests (parents are } \\
\text { not cooperating). }\end{array}$ & (26.3) 9 \\
\hline & $\begin{array}{l}\text { 3-The difficulty of students' } \\
\text { understanding of some } \\
\text { subjects in the absence of } \\
\text { classroom interaction. }\end{array}$ & $(58.8) 3$ & $\begin{array}{l}\text { 3-Lack of time, many } \\
\text { questions, and lack of } \\
\text { experience. }\end{array}$ & (9.9) 13 \\
\hline & $\begin{array}{l}\text { 4-Lack of willingness to } \\
\text { implement the distance } \\
\text { learning system. }\end{array}$ & (43.5) 5 & $\begin{array}{l}\text { 4-Electronic tests will not } \\
\text { show the students' real level } \\
\text { and will not distinguish } \\
\text { students from each other. }\end{array}$ & $(45.4) 5$ \\
\hline & $\begin{array}{l}\text { 5-Get used to face-to-face } \\
\text { learning. }\end{array}$ & (39) 6 & $\longrightarrow$ & \\
\hline \multirow{3}{*}{ Pedagogical obstacles } & $\begin{array}{l}\text { 1-The lack of clarity of the } \\
\text { methods of remote } \\
\text { evaluation. }\end{array}$ & (23.8) 10 & $\begin{array}{l}\text { 1-The answers are very } \\
\text { similar among students. }\end{array}$ & (24.3) 11 \\
\hline & $\begin{array}{l}\text { 2-Lack of preparing the } \\
\text { university community } \\
\text { (administration, professors, } \\
\text { etc.) to deal with distance } \\
\text { learning. }\end{array}$ & (16) 13 & $\begin{array}{l}\text { 2-Some teachers do not have } \\
\text { sufficient experience to } \\
\text { prepare and apply for the test. }\end{array}$ & (23.0) 12 \\
\hline & $\begin{array}{l}\text { 3-Difficulty learning some } \\
\text { applied courses and remotely } \\
\text { oriented work. }\end{array}$ & (16.3) 12 & $\begin{array}{l}\text { 3-The tests did not take into } \\
\text { account the high quality of } \\
\text { design and preparation. }\end{array}$ & $(38.2) 7$ \\
\hline \multirow{3}{*}{ Technical obstacles } & $\begin{array}{l}\text { 1-Weak internet flow } \\
\text { (speed). }\end{array}$ & (59) 2 & $\begin{array}{l}\text { 1-Internet unavailability } \\
\text { and poor internet quality. }\end{array}$ & $(57.9) 3$ \\
\hline & $\begin{array}{l}\text { 2-Security and } \\
\text { confidentiality of data and } \\
\text { information. }\end{array}$ & (32.3) 8 & $\begin{array}{l}\text { 2-There was no real } \\
\text { surveillance, widespread } \\
\text { cases of fraud. }\end{array}$ & $(40.8) 6$ \\
\hline & $\longrightarrow$ & - & $\begin{array}{l}\text { 3-Power cuts (lake of } \\
\text { electricity). }\end{array}$ & (66.4) 2 \\
\hline \multirow{4}{*}{$\begin{array}{l}\text { Financial and organizational } \\
\text { obstacles }\end{array}$} & $\begin{array}{l}\text { 1-The lack of capabilities to } \\
\text { communicate remotely } \\
\text { (devices, internet, Apps, etc.). }\end{array}$ & (59.3) 1 & $\begin{array}{l}\text { 1-Lack of financial and } \\
\text { technical capabilities of some } \\
\text { students. }\end{array}$ & (72.4) 1 \\
\hline & $\begin{array}{l}\text { 2-Lack of training in the use } \\
\text { of technology. }\end{array}$ & (35) 7 & $\begin{array}{l}\text { 2-Parents and students lack } \\
\text { experience with technology. }\end{array}$ & $(37.5) 8$ \\
\hline & $\begin{array}{l}\text { 3-Multiple electronic media } \\
\text { and the absence of uniform } \\
\text { controls between all. }\end{array}$ & (23.5) 11 & $\begin{array}{l}3-\text { Not communicating well } \\
\text { between students and } \\
\text { lecturers. }\end{array}$ & (25.7) 10 \\
\hline & $\begin{array}{l}\text { 4-The home environment is } \\
\text { not suitable for distance } \\
\text { learning. }\end{array}$ & (26.5) 9 & $\longrightarrow$ & - \\
\hline
\end{tabular}

\subsection{Obstacles Arrangement (Ordering)}

Table 3 lists the distance learning obstacles according to their percentage for an overall percentage from 1 to 14 (excluding three non-common obstacles) and showing the breakdown percentage for the similarities and differences between their selection including overall percentage and order number for each obstacle. It also lists obstacles according to their percentage of the exploratory study for both the professors' and students' overall percentage from 1 to 13 (excluding two non-common obstacles). As well, it lists a detailed percentage that explains similarities and differences between their selection including the percentage and ranking of each obstacle to find the breakpoint between the selection of the professors' and students' interests. 
Table 3. Obstacle arrangement to achieving the quality of distance learning and applying electronic exams under the COVID-19 pandemic.

\begin{tabular}{|c|c|c|c|c|c|}
\hline \multicolumn{3}{|c|}{$\begin{array}{c}\text { Distance Learning } \\
\text { Obstacles (Breakdown Percentage } \\
\text { and Arrangement) }\end{array}$} & \multicolumn{3}{|c|}{$\begin{array}{c}\text { Electronic Exams } \\
\text { Obstacles (Breakdown Percentage } \\
\text { and Arrangement) }\end{array}$} \\
\hline $\begin{array}{l}\text { Overall } \\
\text { Percentage } \\
\text { (\%) Order }\end{array}$ & $\begin{array}{l}\text { Professors } \\
\text { Percentage } \\
(\%) \text { Order }\end{array}$ & $\begin{array}{l}\text { Students } \\
\text { Percentage } \\
\text { (\%) Order }\end{array}$ & $\begin{array}{l}\text { Overall } \\
\text { Percentage } \\
\text { (\%) Order }\end{array}$ & $\begin{array}{l}\text { Professors } \\
\text { Percentage } \\
\text { (\%) Order }\end{array}$ & $\begin{array}{l}\text { Students } \\
\text { Percentage } \\
\text { (\%) Order }\end{array}$ \\
\hline (59.3) 1 & (82) 1 & (51.7) 3 & $(72.4) 1$ & (83.5) 1 & (52.7) 1 \\
\hline 2 & (80) 2 & 2 & 3 & (70.1) 3 & (36.4) 4 \\
\hline (58.8) 3 & (60) 9 & (58.3) 1 & (9.9) 13 & (67.0) 4 & (40.0) 3 \\
\hline (44.3) 4 & 6 & (37.3) 4 & (57.2) 4 & $(57.7) 6$ & (23.6) 7 \\
\hline (43.5) 5 & (69) 4 & (35.0) 5 & (45.4) 5 & (49.5) 7 & (25.5) 6 \\
\hline (35.0) 7 & (71) 3 & (23.0) 7 & (37.5) 8 & (58.8) 5 & - \\
\hline (32.3) 8 & (66) 5 & (21.0) 8 & (40.8) 6 & (41.2) 9 & 一 \\
\hline 10 & (47) 11 & (16.0) 10 & (24.3) 11 & (29.9) 11 & (18.2) 9 \\
\hline (23.5) 11 & 10 & 12 & 10 (25.7) & 12 (28.9) & (16.4) 10 \\
\hline 13 & (64) 7 & - & 12 & (36.1) 10 & - \\
\hline (14.8) 14 & 13 & 13 (13.0) & (26.3) 9 & - & (27.3) 5 \\
\hline
\end{tabular}

This comparison was made to find the breakpoint between the overall percentage and selection of the professors' and students' interests in both distance learning and electronic exam obstacles. For example, the order number (highest percentage) means that the biggest obstacle to preventing the achievement of quality in distance learning and electronic exams comes first, and the same concern is provided for the professors but at different concern levels to the students for some obstacles.

\subsection{The Significant Obstacles}

This section presents an argument about the significant differences between the obstacles from the two groups in which some of these obstacles were also found in the high order number. According to Table 4, five obstacles are different in the opinion of professors and students out of the 27 selected obstacles. For example, a power cut (lack of electricity) was selected by professors, students and a high overall percentage with a rank number (2). This obstacle was not shown in distance learning because it was selected from the universities in the governorates of Gaza. Traditional learning system obstacle (e.g., get used to face-to-face learning) got high percentage and order (6) from distance learning but not in the electronic exams selection.

Table 4. The non-common obstacles between distance learning and applying electronic exams.

\begin{tabular}{cccc}
\hline $\begin{array}{c}\text { (Breakdown } \\
\text { Percentage } \\
\text { and Arrangement) }\end{array}$ & $\begin{array}{c}\text { Overall } \\
\text { Percentage } \\
\text { (\%) Order }\end{array}$ & $\begin{array}{c}\text { Professors } \\
\text { Percentage } \\
\text { (\%) Order }\end{array}$ & $\begin{array}{c}\text { Students } \\
\text { Percentage } \\
\text { (\%) Order }\end{array}$ \\
\hline Distance Learning & $(39.0) 6$ & $(61) 8$ & $(31.7) 6$ \\
Obstacles & $(26.5) 9$ & $(46) 12$ & $(20.0) 9$ \\
Electronic Exams & $(16.3) 12$ & $(18) 14$ & $(15.7) 11$ \\
Obstacles & $(66.4) 2$ & $(77.3) 2$ & $(47.3) 2$ \\
\hline
\end{tabular}

\section{Discussion and Result}

The present study explored the obstacles to achieving good quality distance learning and electronic exams from the point of view of the university professors and students that completed questionnaires to find out the effect of the COVID-19 pandemic (see, Tables 1-4). In addition, this study compared obstacles to achieving good quality distance learning and electronic exams in different regions. For example, the weak motivation of students to distance learning and that some professors are not convinced of the usefulness of 
distance learning were indicated. This shows, to some degree, their resistance to the distance learning system and lack of information and awareness of its importance in higher education.

Another challenge comes from electronic exams. Professors and students are largely consistent with what has been found in previous studies in objective areas, such as the lack of financial and technical capabilities of some students and the need for power (electricity) to complete the electronic test; the possibility of using the internet regularly to facilitate the task was considered as one of the most important obstacles to applying simultaneous electronic exams in higher education institutions [42].

Distance learning users face many technical difficulties (e.g., inadequate technological compatibility) that hinder the teaching and learning system, such as students and learners being dissimilar and increased frustration and confusion [43]. George [44] observed that the courses with practical components, compared with courses (without practical components) such as English language and history, can benefit more than other courses in the online learning system. While George [45] shows that learners need the opportunity to approach the course lecturer via email-based correspondence for consultations and exams, which is the most utilized method of consultation when compared with tutorials (classroom) and office-based consultation.

Obviously, the current problem that has been created by the COVID-19 pandemic directly impacted human life and could lead to the global economy shrinking if the restriction of economic activity continues without adequate responsible decisions [14,46]. In addition, the result showed that professors and students were no sure about real monitoring, possibly widespread fraud cases, and they found that electronic tests will not show the true student's level. This was confirmed by Harrison and Bergen [36] as one of the most important defects of electronic tests. Fraud is possible because the test can be submitted by someone else other than the student itself. James (2016) [40] stated that the confidentiality of the tests is not guaranteed due to the absence of a safe and reliable system that can be trusted for electronic tests.

In addition, previous research indicated that the introduction of electronic assessment needs good planning and training $[33,47]$. Their study investigated the impact of a training program for graduate students in designing electronic tests according to the proposed quality standards. This is considered a disadvantage of electronic tests. Obstacles to achieving good quality distance learning and electronic exams during the COVID-19 pandemic were limited to four categories that can be described as follows:

\subsection{Personal Obstacles (Self-Imposed Obstacles)}

In this category, we have nine different obstacles where five belong to distance learning and four to electronic exams, in which the first four obstacles were similar in meaning and comparable as seen in (Tables 2-4). Thus, both professors and students indicated the weak motivation of students to adapt to distance learning and the difficulties faced during critical conditions (e.g., COVID-19 pandemic). Both categories have the same level of concern with the same order (4). In addition, the same level of concern and the same order number of five were appointed for the lack of willingness to implement the distance learning system; furthermore, electronic tests will not show the students' real level and will not distinguish students from each other.

In distance learning, some professors were not convinced of the usefulness of this system, which is consistent with Alumari et al.'s [48] finding; some of the faculty members have a negative perception toward the e-learning system because they believe that it is not important and have a lack of interest in the e-learning system too.

In general, students might wish to change their education system habits including distance learning and exams. They are, however, familiar with traditional (classroom) learning, which may indicate their resistance to changes. Their resistance indicates their unwillingness and feeling of isolation with no interaction with others, which confirms their familiarity with traditional education and learning system. Thus, remote education and 
electronic tests will face resistance Alkhezzi and Al-Zakri, [29] and Liu et al. [15]. This calls for awareness-raising, encouragement, and firmness in order to accept this change.

\subsection{Pedagogical Obstacles}

We explored this category with six different obstacles. They were distributed equally between distance learning and electronic exams. Two of them are similar and comparable to each other, i.e., the lack of clarity of the methods of remote evaluation from distance learning that was similar among students from electronic exams. For the same category, the lack of preparation of the university community (administration, professors, etc.) to deal with a distance learning system was compared too, and some teachers do not have sufficient experience to prepare and apply the test with the same order difference of one.

The third obstacle was not comparable for both groups. Both groups indicated the difficulty of learning to work remotely in some applied courses and worried about exam equality and its preparation. This was confirmed by Bennett [33], that preparing electronic tests require skill and training.

The failure to prepare the university community (e.g., administration, professors, etc.) to deal with distance learning and electronic tests, such as training and preparing electronic courses in advance, using modern programs for presentation, and other logistical capabilities, have prevented the quality of distance learning during COVID-19 pandemic. The lack of clarity of evaluation methods leads everyone to expect difficulties in evaluation and study regarding electronic tests. In addition, this leads to overloading in pedagogical activities in the e-learning environment for the teachers when obtaining feedback to identifying the strengths and weaknesses of students, in addition to other activities such as conducting tests and assignments. This may be due to the lack of use by professors in their communication with students of modern ways of communication, especially e-mail and social networks [49].

\subsection{Technical Obstacles}

Technical obstacles were five for the two groups, two for distance learning and three for electronic exams, two were comparable in meaning and order, i.e., slow internet as compared to poor internet quality in which both of them were mentioned by both professors and students. Issues concerning security and confidentiality of data and information transfer, including protection against piracy on the internet, which affects the electronic courses and exams, were compared to widespread cases of fraud and this is confirmed in [27]. In performing the electronic exams, the professor may not be able to guarantee that the student is not cheating and is not able to prove the student's identity.

In general, professors and students indicated results were very similar in rank, but in assessing these results it is better that the overall percentage be small (e.g., obstacles including cheating) to dispel all existing concerns about the obstacles and obstacles that prevent the achievement of the quality of applying electronic tests remotely under the COVID-19 pandemic, including e-courses and e-tests. In an online environment, students often conduct the tests on their electronic devices (such as cell phones, iPads, computers, tablets, etc.) in their homes. As a result, there is a potential for unethical behavior by students [50].

Professors and students indicated that one of the most important obstacles to achieving quality of applying electronic tests during the COVID-19 pandemic was power cuts. Universities in Gaza have been suffering from a shortage of power for a long time. The consequent interruptions in transmission and obstruction to follow-up of lessons, and perhaps student's distraction from communication and security of the data and information, are very annoying. This affects the courses, lessons and exams and their results. This is confirmed by Jawida et al. [27], that security is one of the main problems facing distance learning during the performance of electronic exams. 


\subsection{Financial and Organizational Obstacles}

In total, seven obstacles were financial and organizational. Three of these were similar and only the last one belongs to distance learning. Thus, the obstacles were selected by professors and students in favor of financial and organizational categories from different regions and according to their viewpoint. The three common obstacles were very important, e.g., the lack of capabilities to communicate remotely (devices, internet, Apps, etc.) was compared to the lack of financial and technical capabilities of some students.

A large number of professors and students indicated the lack of remote communication capabilities (devices, internet, applications, etc.), and this is consistent with the findings in [48]. They state the difficulty of funding for obtaining computers for some students. This is consistent with the findings by Jawida et al. [27], and the need for professors and students to train on the use of the internet [51]. He recommended training programs at the university to train all faculty members. This was confirmed by Alumari et al. [48] There is a general difficulty of dealing with uncooperative learners who are not trained in self-learning, the difficulty of ensuring that students can use the computer skills, and the lack of computer-trained instructors.

\subsection{Additional Findings}

This study aimed to explore and compare different obstacles to achieving quality distance learning and applying electronic exams during the COVID-19 pandemic. Tables $2-4$ presented a comparison between the answers of professors and students and between distance learning and electronic exams. There are differences in percentages that may be because of better understanding from the professors of the students' conditions and situation, particularly those with low income living in villages and remote areas with minimum life standards.

Table 3 clearly shows the obstacles to achieving good quality distance learning and applying electronic exams in the COVID-19 pandemic. In general, in evaluating these results, it is better that the overall percentage be low to dispel all the existing concerns about the obstacles and obstacles that prevent the achievement of good quality application of distance learning and electronic tests.

It was also clear from all responses that the home environment is not suitable for remote learning and testing, due to the influence of family, narrow spacing of some houses, and the presence of a large number of learners (family members) in the family with one computer if any. All these obstacles can prevent the quality of learning and e-tests during the COVID-19 pandemic or similar crisis. The discrepancy between most of the ratios in some of the samples may be due to students having significant delays in their registration of the study programs in distance education, particularly those that are using the internet in direct broadcast, and the frequent preoccupation of students from the surrounding environment and questionings and their fears about how to evaluate them from a distance.

Looking at one row in Table 3, 52\% of the professors stated that there is an effect from the use of multiple electronic media and the absence of uniform controls between all members in distance learning compared to $28.9 \%$ who stated that they were not communicating well between students and lecturers in the electronic test. This also was stated by students in which there was $14 \%$ from distance learning compared to $16.4 \%$ from the electronic test, while 23.5 and $25.7 \%$ for overall percentages, respectively.

It is also observed that, for the same row, the orders were very close to each other and ranged between 10 and 12. The small differences in the proportions between the two samples may be because the universities' location and region did not vary from each other in their situation; though, in critical situations, they have to work together to recover the effect from the use of multiple electronic media to improve the communication between students and lecturers. 


\section{Conclusions (and Recommendations)}

This study investigated the current situation under the COVID-19 pandemic at some universities in Algeria, Egypt, Iraq, and Palestinian universities in the governorates of Gaza. These universities combine traditional and modern forms of distance education. Most universities use the internet but without full knowledge of the obstacles that can prevent quality achievement of distance (online) learning and electronic testing [50].

However, distance learning and electronic testing have become an urgent necessity for higher education institutions. Calling for a modern educational system and integration of technology could, in fact, be a positive reaction that can create flexibility in the learning environment to achieve a secured educational system, improving university results. As you can see, we have concentrated just on the comparisons between obstacles of the two faces of distance education as a whole system. After this study, we plan to continue working on the distance education system components to produce more beneficial studies, especially for e-tests with specific problems that have possible solutions. This study provided some suggestions to reduce or minimize the effect of the COVID-19 pandemic that are listed as follows:

1. Improving the university infrastructure by employing technical supervisors to lower the load of professors and students.

2. Providing various e-learning and e-exam applications for optimal use of technologies through the internet.

3. There should be a number of resources and strategies available to faculty members to address potential problems.

4. Securing the internet service and electrical current to all students in all areas.

5. Helping students to reduce unethical behavior in the internet environment; for more information see Bennett [33].

6. Preparing electronic courses and sample tests at a high level of quality at the university's websites for the public benefit.

7. Training and continuing education opportunities must be provided for all; it should be required in the new roles that professors and students apply for.

8. The study suggests expanding the sample size in the future, which could provide wider results for more understanding.

Author Contributions: Conceptualization, R.B. and M.A.; methodology, R.B. and Z.L.; validation, R.B., Z.L. and M.A.; formal analysis, Z.L. and R.B.; investigation, M.A.; resources, R.B., Z.L. and M.A.; data curation, R.B. and M.A.; writing-original draft preparation, R.B., Z.L. and M.A.; writingreview and editing, R.B. and Z.L.; visualization, R.B., Z.L. and M.A. All authors have read and agreed to the published version of the manuscript.

Funding: This research received no external funding. The APC was funded by Lund University.

Institutional Review Board Statement: Not applicable.

Informed Consent Statement: Not applicable.

Data Availability Statement: Not applicable.

Acknowledgments: Thanks to the Center for Middle Eastern Studies (special thanks to Ronny Berndtsson) and Lund University for their effort and support.

Conflicts of Interest: The authors declare no conflict of interest.

\section{References}

1. World Health Organization. Corona Virus Disease (COVID-19): Question and Answer. 2020. Available online: https://www. who.int/ar/emergencies/diseases/novel-coronavirus-2019/advice-for-public/q-a-coronaviruses (accessed on 17 May 2020).

2. Shivangi, D. Online learning: A panacea in the time of COVID-19 crisis. J. Educ. Technol. Syst. 2020, 49, 5-22. [CrossRef]

3. Evgueni, K.; Mariana, P. Information and Communication Technologies in Teacher Education: A Planning Guide. Division of Higher Education; Document code: ED/HED/TED/3; UNESCO: Paris, France, 2002.

4. Bennett, R.E. Online Assessment and the Comparability of Score Meaning; Educational Testing Service: Princeton, NJ, USA, 2003. 
5. Dahdy, I.; Meziani, A. Educational calendar. Its concept and its importance. J. Hum. Sci. 2017, 9, 115-126. Available online: https:/ / www.asjp.cerist.dz/en/article/78536 (accessed on 10 October 2020).

6. Al-Ghomlas, K. Remote Calendar, My University Newspaper, Prince Sattam bin Abdulaziz University. September 2020. Available online: https://np.psau.edu.sa/ar/article/2020/08/159844425 (accessed on 17 August 2020).

7. Bahmawi, H.; Lamir, N. The Impact of Educational Evaluation Methods in the Context of Comparative Pedagogy with Competencies on the Pattern of Learner Achievement. Master's Thesis, University of Adrar, Adrar, Algeria, 2014.

8. Basilaia, G.; Dgebuadze, M.; Kantaria, M.; Chokhonelidze, G. Replacing the classic learning form at universities as an immediate response to the COVID-19 virus infection in Georgia. Int. J. Res. Appl. Sci. Eng. Technol. 2020, 8, 101-108. [CrossRef]

9. Liguori, E.W.; Winkler, C. From offline to online: Challenges and opportunities for entrepreneurship education following the COVID-19 pandemic. Entrep. Educ. Pedagog. 2020. [CrossRef]

10. Abdelhai, R.A. Distance Education in the Arab World and the Challenges of the Twenty-First Century; The Anglo-Egyptian Bookshop: Cairo, Egypt, 2010.

11. UNESCO. Distance Education in the Corona Virus Pandemic. Available online: https://en.unesco.org/covid19/educationresponse (accessed on 17 May 2020).

12. Khalaf, Z.N. Corona Virus and Digital Equality in Tele-Teaching in Emergency Situations. New Education Blog. Available online: https: / / www.new-educ.com/ / (accessed on 17 May 2020).

13. Huang, R.H.; Liu, D.J.; Tlili, A.; Yang, J.F. Handbook on Facilitating Flexible Learning during Educational Disruption: The Chinese Experience in Maintaining Undisrupted Learning in COVID-19 Outbreak; Smart Learning Institute of Beijing Normal University: Beijing, China, 2020.

14. Girik, A.M.D. Is the online learning good in the midst of Covid-19 Pandemic? The case of EFL learners. J. Sinestesia 2020, 10, 1-8.

15. Liu, I.F.; Chen, R.S.; Lu, H.C. An exploration into improving examinees' acceptance of participation in online exam. Educ. Technol. Soc. 2015, 18, 153-165.

16. Fluck, A.; Pullen, D.; Harper, C. Case study of a computer based examination. J. Educ. Technol. 2009, 25, 509-523. [CrossRef]

17. Ranne, S.C.; Lunden, O.; Kolari, S. An alternative teaching method for electrical engineering course. Proc. IEEE Trans. Educ. 2008, 51, 423-431. [CrossRef]

18. Carey, K. Is everybody ready for the big migration to online college? Actually, no. The New York Times. 13 March 2020. Available online: https://www.nytimes.com/2020/03/13/upshot/coronavirus-online-college-classes-unprepared.html (accessed on 13 October 2020).

19. Holmberg, B. Distance Education: A Survey and Bibliography; ERIC: London, UK, 1977.

20. Sadiq, A. Theoretical Foundations of Distance Education. Teacher Magazine. 2004. Available online: http://www.almaulem. netAl- (accessed on 17 May 2020).

21. USDLA (US American Distance Education Association). Definition of Distance Learning. 2004. Available online: http//www. usdla.org/ (accessed on 20 May 2020).

22. Singh, V.; Thurman, A. How many ways can we define online learning? A systematic literature review of definitions of online learning (1988-2018). Am. J. Distance Educ. 2019, 33, 289-306. [CrossRef]

23. Al-Farra, I.S. Distance learning and open education: Roots, concepts, and justifications. Palest. J. Open End. Educ. 2007, 1, 11-60.

24. Lassoued, Z.; Alhendawi, M.; Bashitialshaaer, R. An exploratory study of the obstacles for achieving quality in distance learning during the COVID-19 pandemic. Educ. Sci. 2020, 10, 232. [CrossRef]

25. Jawda, P.S.O.; Rashid, P.D.H.; Aboud, A.P.D.Z.M.; Jawad, A.P.D.S.A. University education remote concept and the extent of their applicability. Alustath J. Hum. Soc. Sci. 2016, 216, 139-158. [CrossRef]

26. Al-Saleh, B.A. Critical issues in e-learning distance education model. In Proceedings of the Third International Conference for e-Learning via Distance Learning, Riyadh, Saudi Arabia, 2 February 2013; pp. 4-7.

27. Jawida, A.; Tarshun, O.; Alyane, A. Characteristics and objectives of distance education and e-learning-A comparative study on the experiences of some Arab countries. Arab J. Lit. Hum. 2019, 6, 285-298.

28. Al-Khayyat, M. Students and instructor attitudes toward computerized tests in Business Faculty at the main campus of Al-Balqa Applied University. An-Najah Univ. J. Res. Hum. Sci. 2017, 31, 2041-2072.

29. Alkhezzi, A.F.; Al-Zakri, M.I. Equivalence of electronic tests with paper tests in measuring academic achievement: An experimental study on students of the College of Education at Kuwait University. J. Gulf Arab. Penins. Stud. 2011, 143, 2-32.

30. AlSmadi, A. Measurement, Psychological and Educational Evaluation, 1st ed.; Wael House: Amman, Jordan, 2004.

31. Ryan, S.; Scott, B.; Freeman, H.; Patel, D. The Virtual University: The Internet and Resource-Based Learning; Kogan Page: London, UK, 2000.

32. Wiechmann, D.; Ryan, A. Reactions to computerized testing in selection contests. Int. J. Sel. Assess. 2003, 11, 215-229. [CrossRef]

33. Bennett, R.E. How the internet will help large-Scale assessments reinvent itself. Educ. Policy Anal. Arch. 2001, 9, 1-23. [CrossRef]

34. De Beer, M.; Visser, D. Comparability of the paper-and-pincil and computerized adaptive virsion of the general scholastic aptituede test (GSAT) senior. S. Afr. J. Psychol. 1998, 28, 21-27. [CrossRef]

35. Schmit, M.; Ryan, A. Test-taking disposition: A missing link? J. Appl. Psychol. 1993, 77, 629-637. [CrossRef]

36. Harrison, N.; Bergen, C. Some design strateges for developing an online course. Educ. Technol. 2000, 40, 57-60.

37. Wise, S.; Plake, B.S. Research on the effects of administering tests via computers. Educ. Meas. Issues Pract. 1989, 8, 5-10. [CrossRef] 
38. Martin, A. How to Optimize Online Learning in the Age of Coronavirus (COVID-19): A 5-Point Guide for Educators. Available online: https://www.researchgate.net/publication/339944395_How_to_Optimize_Online_Learning_in_the_Age_of_Coronavirus_ COVID-19_A_5-Point_Guide_for_Educators (accessed on 30 July 2020).

39. George, M.L. Effective teaching and examination strategies for undergraduate learning during COVID-19 school. J. Educ. Technol. Syst. 2020, 49, 23-48. [CrossRef]

40. James, R. Tritiary student attitudes to invigilated online summative examination. Int. J. Educ. Technol. 2016, 13, 2-13.

41. Stowell, J.; Bennett, D. Effect of online Testing on student exams performance and text anxiety. J. Educ. Comput. Res. 2010, 42, 161-171. [CrossRef]

42. Thomas, P.; Price, B.; Paine, C.; Richards, M. Remote electronic examinations: Student experiences. Br. J. Educ. Technol. 2002, 33, 537-549. [CrossRef]

43. Favale, T.; Soro, F.; Trevisan, M.; Drago, I.; Mellia, M. Campus traffic and e-Learning during COVID-19 pandemic. Comput. Netw. 2020, 176, 107290. [CrossRef]

44. George, M.L. An effective classroom-based approach for teaching digital logic design to engineering undergraduates. Int. J. Innov. Res. Dev. 2018, 7, 45-53.

45. George, M.L. Study on the effect of tutorial, email and office consultations on undergraduate performance in the topic of finite state machines. Int. J. Adv. Sci. Technol. 2020, 29, 1225-1233.

46. Suminar, A. Dampak Covid-19 Terhadap Ekonomi Global. 2020. Available online: https://www.suarasurabaya.net/ ekonomibisnis/2020/dampak-covid-19-terhadap-ekonomi-global-2020/ (accessed on 10 August 2020).

47. Mandour, E.M. The effect of a training program for postgraduate students at the College of Education on designing electronic tests according to the proposed quality standards. J. Educ. Soc. Stud. 2013, 19, 391-460.

48. Alumari, M.M.; Alkhatib, I.M.; Alrufiai, I.M.M. The reality and requirements of modern education methods-Electronic Learning. Al-Dananeer Mag. 2016, 9, 37-56.

49. Falta, E.; Sadrata, F. Barriers to using e-learning to teach masters students at the Algerian University. Arab J. Media Child Cult. 2019, 6, 17-48.

50. Williamson, M.H. Online exams: The need for best practices and overcoming challenge. J. Public Prof. Sociol. 2018, 10, 16-23.

51. Jadee, M. Attitudes of faculty members towards conducting electronic tests and the obstacles to their application at the University of Tabuk. Spec. Int. Educ. J. 2017, 6, 77-87. 